\title{
The Effect of In-Service Training Courses on Teacher Achievement: A Meta-analysis Study
}

\author{
Nuri Balta ${ }^{1}$, Mustafa Arslan ${ }^{1} \&$ Hüseyin Duru ${ }^{1}$ \\ ${ }^{1}$ Faculty of Education, Canik Basari University, Samsun, Turkey \\ Correspondence: Nuri Balta, Faculty of Education, Canik Basari University, Samsun, Turkey
}

Received: July 14, 2015 Accepted: July 31, 2015 Online Published: August 12, 2015

doi:10.11114/jets.v3i5.1037 URL: http://dx.doi.org/10.11114/jets.v3i5.1037

\begin{abstract}
One of the ways for teachers to improve classroom activities and student achievement is to receive in-service training (IST). This study examines theses that deal with the effects of IST on teachers' achievement by means of meta-analysis. A total of five theses, chosen through screening conducted by specified criteria, were included in this meta-analysis. The effect sizes, obtained from these presented theses, were combined, a common effect size belonging to the efficiency of IST courses (Hedge's g =3.819) was calculated and the organized IST courses were determined to be highly effective within the thesis. It was revealed that there were not enough studies conducted in Turkey that measure the empirical effectiveness of IST and exploring the effectiveness of IST courses was demonstrated to be a virgin area for researchers.
\end{abstract}

Keywords: in-service training, professional development, meta-analysis, teacher achievement

\section{Introduction}

\subsection{In-service Training}

Theories, strategies, methods, technologies and curricula on education change over time. Teachers require in-service training (IST) in order to adapt themselves to these changes (Demirtaş, 2010). In order words, one of the ways for teachers who were already employed to gain access to new developments in education and educational technologies is to receive IST. According to the results of many reports and researches, the quality of schools depends on teachers' capacity and their professional development (Borko, 2004; Fendler, 2003; Garet, Porter, Desimone, Birman, \& Yoon, 2001). "Teachers have a dramatic impact on students' positive development and the overall success of their classrooms" (Castillo, Fernández-Berrocal, \& Brackett, 2013). Field experts indicated that the success would be low if teachers were not placed at the center in educational policies (Dori and Herscovitz, 2005). Teachers' continuance of their professional development through IST is one of the main characteristics of executing successful education at schools. Attracting attention to this issue, Birman et al. (2000) draw attention to IST programs that are prepared for teachers in order to fill the gap between developments in education and preparing teachers for instruction.

The ultimate aim of IST programs are to ensure the effectiveness of teachers in the classroom and to increase student achievement consequently (Hewson, 2007). A directly proportional relationship was determined between the professional experiences of teachers and their participation in IST programs (Balta, 2014). It is also known that the more teachers participate in IST programs, the more student success will be achieved (Damar, 1996).

While this important benefit of IST courses is in view, IST courses are not professionally addressed in Turkey (Özer, 2014). IST programs at an institution should be planned and executed well in order to ensure the expected benefits of IST activities. IST programs, especially designed for teachers, must bring solutions to the problems they encounter in education. Otherwise, timewise and materialistic losses arise. One of the examples of how IST courses are not handled professionally was the report prepared by the University of Twente (OOPEU, 2010). According to this, while 75\% of the programs organized in Turkey were in the form of seminars, $92 \%$ of these programs in Austria, 93\% in Estonia and 93\% in Lithuania were organized as workshops within the period of 18 months covering 2007-2008. IST courses, organized in Turkey for contributing to the life-long learning of teachers, are way beyond standards and do not carry the features of effective professional development programs (Balta, 2014).

According to another result of the same report, Turkey is again the only country among the countries of the European Union to prepare the least number of professional development programs for teachers. Gönen ve Kocakayan (2006) also 
obtained similar results to this report. According to Gönen and Kocakayan, 19\% of physics teachers were identified never to participate in IST courses and 34\% of them participated in these courses one or two times after they started their jobs. Physics teachers, who participated in the same study, replied as necessary by $75 \%$ and partially necessary by $18 \%$ to another statement regarding the necessity of IST courses. Even though teachers consider IST courses to be necessary for their professional developments, it is a great deficiency not to organize this kind of training courses professionally and in a way to include all of the teachers.

IST courses, organized by the General Directorate of Teacher Training and Development in 2012, 2013, and 2014, provide sufficient information on the nature of programs carried out in Turkey. In 2012, a total of 562 courses, including central and local, were planned and 181 of them were later canceled (HIEP, 2014). No courses were organized in mathematics, biology and chemistry and only one course was executed in physics (for the National Physics Olympiad). These courses, mostly organized in the form of seminars like Köyalan and the University of Twente report (OOPEU, 2010) stated, cover periods ranging from 2 days to 103 days. $62 \%$ of these courses were carried out during the holiday season and 16 of them were designed to improve teachers' knowledge of English language. Courses were programmed to have different contents such as "Calibration of Biomedical instruments" and "Mentally Handicapped Training Course". Not much change was made in the contents of the courses held by the year 2013. During this period, only three measurement and assessment seminars were organized for group leaders of mathematics, physics, chemistry, biology, Turkish language and literature, history, geography, religious culture and ethics courses working secondary schools under the General Directorate of Secondary Education. Similarly, a total of 310 courses were planned in 2014, and 34 of these courses were cancelled by September (2014). In 2014, some field courses were relatively given place, but these courses were still not subject-oriented and were organized generally in teaching methods and techniques of the courses. In the time-span of three years, courses, which mostly involved language, information technologies, measurement and assessment, psychological counseling and guidance, vocational high schools and pre-schools, were organized and they were generally courses that were far from increasing knowledge on the field. The number of courses, which were organized, are rather less when compared to the number of teachers in our country. For example, when the number of teachers (78244) that rendered service in 2013-2014 academic year was compared with the number of courses (197) organized in 2013, about 4000 teachers fall for per course (AE, 2014). Also, a total of 25284 teachers participated in 197 courses organized in 2013, and about 3\% of teachers received IST.

In order to increase the effectiveness of IST courses in Turkey, researchers as well as the relevant government agencies (except for few theses), unfortunately, could not generally go beyond conducting needs analysis and identifying problems in these courses. Needs analysis were mostly conducted to determine the contents of the courses. On the other hand, needs analysis, conducted without taking expert opinions, misled those who organized IST courses. Since the content that was identified as a result of needs analysis does not contain the field knowledge, it indicates that analysis were not comprehensive or adequate. For example, class teachers and subject teachers, who participated in the research conducted by Günbayı and Taşdöğen (2012), specified the contents of IST courses that they would like to participate as such: promotion of new programs, methods and techniques, speed reading, computer programming, special education, teaching English, emotional intelligence and NLP, personal development, Commenius - Socrates, communication, drama, national placement test (SBS), child rights, classroom management, making mathematics a fun course, psychology, field and National Education. Another study, which may be an example for an incomplete needs analysis, is the study conducted by the Ministry of Education and Association of Research and Development of Education (EARGED) on class teachers called "determination of class teachers' needs for in-service training." According to this study, the issues that need to be addressed primarily in IST courses are listed as follows: new approaches in education, stress coping methods, developing and using measurement and assessment tools, teaching children whose instructions develop differently through plays, use of new educational technologies, reactions observed in the families of children in need of special education and their solutions, characteristics of autistic and gifted children who display learning difficulties, lack of attention and hyperactivity disorder, and measurement and assessment for group learning activities (MEB, 2008). The recommended programs, as can be understood, are far from containing content knowledge which is one of the features of effective professional development programs.

Standard-based IST programs must be able to increase the content and pedagogical knowledge of teachers which are the indicators of classroom activities (Blank and Alas, 2010). Researchers (Loucks-Horsley,1995; Darling-Hammond,1996; Hawley \& Valli, 1998; Birman, Desimone, \& Porter, 2000; Joyce \& Showers, 2002; Guskey, 2003; Corcoran, 2007; Yoon et al., 2007; Desimone, 2009; Wei et al., 2009; Tanriverdi \& Günel, 2012) consider IST course or professional development programs that are (a) delivered in conductive setting, (b) enabling collective participation, (c) making active learning possible, (d) increasing content knowledge, (e) coherence, (f) intensive (the courses, which are under 14 hours, are considered to be ineffective according to the literature), (g) sustained, (h) long duration and (i) job embedded. In recent years, increasing number of studies on the field of IST in Turkey can be divided into two categories. The first 
(are carried out quite a few in numbers), developing IST models or programs and searching their effects on the participants. The second, they are implemented in many numbers, and searches the attitudes of teachers towards the organized IST courses and problems that emerge in these courses. Researches, which fall into the first category, are generally carried out at universities as thesis studies and researches, which fall into the second category, are generally conducted as research papers. Only quantitative studies, in the first category, are appropriate for the objectives of this meta-analysis research.

\subsection{Meta-Analysis}

The increase in the number of studies on specific topics in the field of educational science created the need for comprehensive and systematic research synthesis. The meta-analysis, one of these research methods, is encouraged as an effective way to synthesize research in many fields including social sciences and educational sciences (Üstün and Eryllmaz, 2014). Meta-analysis, defined as the analysis of analysis, is the process of combining numerous results obtained in individual studies with a new statistical analysis method (Glass, 1976). Collecting and scanning the existing publications with common subjects and interpreting the information found inside them according to certain criteria are the basic logic of meta-analysis. In this respect, the obtained results of meta-analysis can be compared to the conversion of a hypothesis, supported by several tests, into a scientific law.

\subsection{Aim and Research Question}

In recent years, several IST course models are developed at universities in Turkey and their effectiveness is being studied. There is a need to make generalizations after synthesizing the studies conducted in this field so far. The aim of this meta-analysis is to examine the impact of IST courses on teachers after combining thesis works conducted in the field of IST at universities in line with the steps of meta-analysis. Another aim of this research is to identify the effective features of IST courses organized for scientific research and to divert the attention of the authorities, which organize similar courses, to these features. This study possesses the following research question:

What is the strength of the relationship between in-service training courses and teacher achievement?

\section{Method}

The efficiency of IST courses was attempted to be uncovered in this study. Firstly, the criteria for conducting necessary eliminations and selecting researches that would be included in meta-analysis were identified. Then, literature review and encoding process were carried out.

\subsection{Criteria}

Topic: Relevant thesis works on IST.

Population: Studies conducted on teachers working in the institutions of National education.

Design: Studies that conducted pre-test and post-test in order to discover the effectiveness of IST courses.

Outcome: Studies that examine the effects of IST courses on teachers' achievement.

Period: No time limitation was imposed on the studies to be included in meta-analysis.

Country: Studies carried out in Turkey.

Literature: Thesis works that were prepared at universities.

\subsection{Unit of Analysis and Validity}

Since each of the primary studies in this meta-analysis is the thesis works, they are independent. However, the effect size was accepted as the unit of analysis. This meta-analysis work does not have any validity problem in terms of publication bias. In other words, there is no problem for studies with statistically significant results to have higher possibility of being published. Researchers publish their thesis works at any case whether they obtained positive or negative results in them. On the other hand, thesis works' guidance by thesis monitoring committees, and conduction of validity and reliability tasks to the measuring tools used adequately increase the quality of thesis.

\subsection{Screening and Coding Processes}

Screening and coding processes were carried out in three stages after combining two of the four stages suggested by Yoon et al. (2007). These are literature review, the process of reading thesis works and coding stage as in Figure 1. 


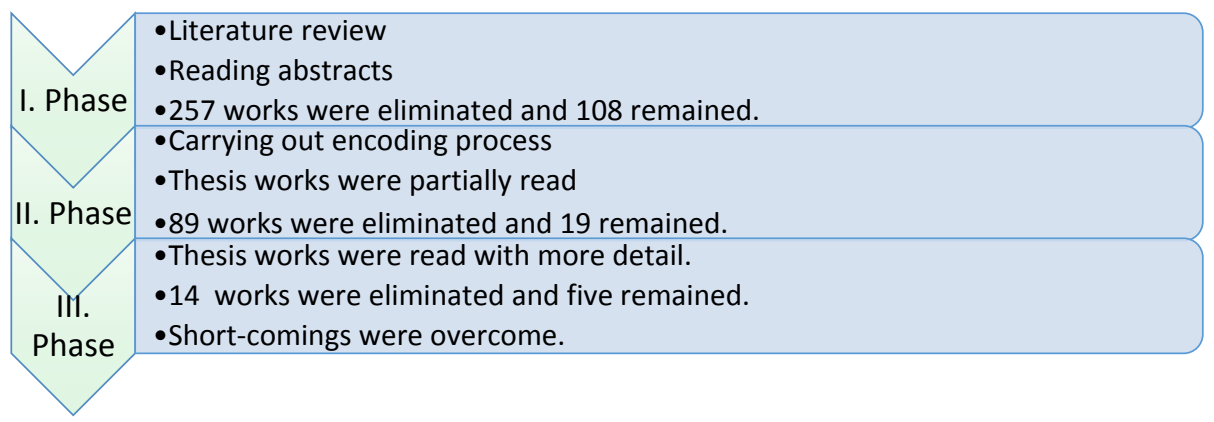

Figure 1. Scanning and encoding process

\subsubsection{Phase-I}

Thesis works, which would be included in meta-analysis, were identified by systematical screening conducted at Higher Education Council thesis center. Thesis center was scanned with the following keywords: In-service training, in service training, inservice training, career development and professional development. A total of 442 thesis works were found with specified keywords. A sum of 365 theses on IST were identified after sorting out common works found by different keywords.

The abstracts of the works were scanned after they were discovered with keywords in literature review. In this phase, firstly thesis works that measure the effectiveness of IST, covering teachers and quantitative studies were identified. Secondly, 108 works out of 365 were assessed in the next phase since they did possess the specified criteria. Thirdly, not measuring the effectiveness of IST mostly become a reason for elimination. Others were mostly on the training of staff working in institutions outside of National Education and were qualitative researches. Therefore they were not taken into consideration.

\subsubsection{Phase-II}

A detailed coding form was created according to the specified criteria and analysis to be carried out. The characteristics of the studies were recorded in this form prepared in Microsoft Excel step by step and studies that passed the first elimination stage were examined in the second stage. Coders only paid attention to the places in theses, where they could obtain information in order to fill the coding form. They mostly read the methodology and findings sections of the studies completely. Two different coders coded the studies that they scanned according to the specified criteria and identified similar features from the studies at the rate of $94 \%$. In this phase, coders, at the same time, resolved the issues that they did not agree upon after discussing among themselves. Two more criteria were identified in this phase in addition to the three criteria (studies that include teachers, those that measure the effectiveness of IST, and quantitative studies) in the first phase: studies that apply pre-test and post-test and those that provide necessary data for the calculation of the effect size. More 89 studies, out of 108, which passed the first elimination, were eliminated at this phase because they were not considered to be suitable. At this phase, the inability to obtain the necessary data for the calculation of effect sizes was the biggest cause of elimination.

\subsubsection{Phase-III}

In the final phase, the incomplete parts of the coding form (year of the study, province where the study was conducted, subject in which the study was conducted upon, the school level, duration of IST, type of IST, number of participants, university where the study was conducted and type of the study), for the remaining five works, were completely filled and the effect sizes of the selected studies were calculated. If any missing information was detected in any of the selected five studies, researchers, who conducted that particular study, was contacted and this information was successfully completed.

\section{Findings and Comments}

The main features of the five studies selected for meta-analysis, the effect sizes of the studies included in meta-analysis, their characteristics and statistical analysis were separately examined in findings and comments section.

\subsection{Main Features of the Studies Included in Meta-analysis}

A total of five thesis works were chosen for meta-analysis in this research as a result of the criteria defined and eliminations conducted. The main features of these thesis works are given in Table 1. 
Table 1. Main Features of the Studies Included in Meta-analysis

\begin{tabular}{|c|c|c|c|c|c|c|c|c|}
\hline Researcher & Design & & Course & Institution & Measured Con & ruct & & \\
\hline $\begin{array}{l}\text { Metin, } \\
2010\end{array}$ & $\begin{array}{l}\text { Pre-test, } \\
\text { Single group }\end{array}$ & post-test & $\begin{array}{l}\text { Science and } \\
\text { technology }\end{array}$ & $\begin{array}{l}\text { Secondary } \\
\text { school }\end{array}$ & $\begin{array}{l}\text { Achievement } \\
\text { measured. }\end{array}$ & of & teachers & were \\
\hline $\begin{array}{l}\text { Tekin, } \\
2004\end{array}$ & $\begin{array}{l}\text { Pre-test, } \\
\text { Single group }\end{array}$ & post-test & Chemistry & High school & $\begin{array}{l}\text { Achievement } \\
\text { measured. }\end{array}$ & of & teachers & were \\
\hline $\begin{array}{l}\text { Şenel, } \\
2008\end{array}$ & $\begin{array}{l}\text { Pre-test, } \\
\text { Single group }\end{array}$ & post-test & $\begin{array}{l}\text { Science and } \\
\text { technology }\end{array}$ & $\begin{array}{l}\text { Secondary } \\
\text { school }\end{array}$ & $\begin{array}{l}\text { Achievement } \\
\text { measured. }\end{array}$ & of & teachers & were \\
\hline $\begin{array}{l}\text { Balta, } \\
2014\end{array}$ & $\begin{array}{l}\text { Pre-test, } \\
\text { Single group }\end{array}$ & post-test & Physics & High school & $\begin{array}{l}\text { Achievement } \\
\text { measured. }\end{array}$ & of & teachers & were \\
\hline $\begin{array}{l}\text { Yadigaroğlu, } \\
2014\end{array}$ & $\begin{array}{l}\text { Pre-test, } \\
\text { Single group }\end{array}$ & post-test & Chemistry & High school & $\begin{array}{l}\text { Achievement } \\
\text { measured. }\end{array}$ & of & teachers & were \\
\hline
\end{tabular}

All studies presented in Table 1 have single group pre-test post-test design for measuring teachers' achievement. Among them one measured only teacher achievement (Tekin, 2004), one focused on only teacher and student achievement (Balta, 2014), and three searched achievement and attitudes of teachers (Metin, 2010; Şenel, 2008; Yadigaroğlu, 2014). For the purpose of this meta-analysis only the construct "achievement" is taken into account. Two at secondary and three studies at high school level were found to be suitable to the specified criteria. According to Table 1, out of five, two studies were conducted in Science and Technology, two in Chemistry and one in Physics course. The table indicates that the studies that assess the effectiveness of IST were conducted within a very narrow time-span like 2004-2014.

\subsection{The Effect Sizes of the Studies Included in Meta-analysis}

The effect size can simply be defined as the ratio of the difference in the averages of the two groups to the pooled standard deviation of the groups (Cohen, 1988). The effect size is a standardized size that indicates the effect of a conducted application on the dependent variable and enables the comparison of many different studies. In the definition of Özsoy and Özsoy (2013), it can be defined as the "standardization of the difference between averages" or "standardized measurement of the relationship." The classification, made by Cohen (1988), can be used in order to render the effect size significant for educators and politicians. Cohen classified the effect size as $d=0,2$ small, $d=0,5$ medium and $\mathrm{d}=0,8$ big.

A total of six effect sizes (Hedge's g) were calculated from the five studies selected as a result of the eliminations and thus, unit of analysis is the effect size in this meta-analysis. The average effect size, measuring tool and the level of effect size were indicated in Table 2.

Table 2. The Effect Sizes of the Studies Included in Meta-analysis

\begin{tabular}{llcc}
\hline Study & Measurement Tool & Average ES & Cohen's d \\
\hline Metin, 2010 & Achievement Test & 4.99 & Large \\
Tekin, 2004 & Achievement Test & 4.41 & Large \\
Şenel, 2008 & Achievement Test & 7.53 & Large \\
Balta, 2014 & Achievement Test & 0,86 & Large \\
Yadigaroğlu, 2014 & Achievement Test - multiple choice & 3.46 & Large \\
& Achievement Test - open ended & 3.33 & Large \\
\hline
\end{tabular}

As seen in Table 2, all effect sizes are large as classified by Cohen (1988). The effect sizes reported for each study indicate that the average of 4.10 effect sizes fall per study. In this meta-analysis research, out of six effect sizes, calculated on the achievement of teachers in the organized IST courses, none had negative impact. In three studies, very big effect sizes, 4,99; 4.41; and 7.53 respectively were found in Metin's (2010), Tekin's (2004), and Şenel's (2008) studies.

\subsection{Contents of the Studies Included in Meta-analysis}

The contents and some other features (contact hour/duration, university/thesis/city, and type of course/number of participants) of the studies that provide criteria for meta-analysis were shown in Table 3.

As can be understood from the findings obtained (Table 3), among the studies included in meta-analysis, except the sole study conducted in Middle East Technical University all others were masters and $\mathrm{PhD}$ thesis works run at Karadeniz Technical University. The contact hour of courses related to IST varied, at the average of 38.2 hours, from the shortest course of 21 hours to the longest course of 60 hours. Similarly, the duration of the courses varies from 10 days to seven weeks. The participants of the courses consisted of at least 6 (Şenel, 2008; Balta, 2014) and at most 25 (Metin, 2010; Tekin; 2004) teachers. The studies, included in the meta-analysis, were conducted for the last ten years (between 2004 and 2014). 
Table 3. Contents of the Studies Included in Meta-analysis

\begin{tabular}{|c|c|c|c|c|}
\hline Researcher & Content & $\begin{array}{l}\text { Contact } \\
\text { hour/ } \\
\text { Duration }\end{array}$ & $\begin{array}{l}\text { University/T } \\
\text { hesis/ } \\
\text { Province }\end{array}$ & $\begin{array}{l}\text { Course type/ } \\
\text { Participant }\end{array}$ \\
\hline $\begin{array}{l}\text { Metin, } \\
2010\end{array}$ & $\begin{array}{l}\text { It researched the impact of IST course organized for } \\
\text { performance evaluation of Science and Technology } \\
\text { teachers. }\end{array}$ & $\begin{array}{l}60 \text { hours } \\
12 \text { days }\end{array}$ & $\begin{array}{l}\text { Karadeniz } \\
\text { Tech. Uni. } \\
\text { Ph.D. } \\
\text { Artvin }\end{array}$ & $\begin{array}{l}\text { Workshop } \\
25 \text { teachers }\end{array}$ \\
\hline $\begin{array}{l}\text { Tekin, } \\
2004\end{array}$ & $\begin{array}{l}\text { An IST course, aimed at identifying the conceptual } \\
\text { understanding levels of the chemistry teachers and help } \\
\text { them procure professional knowledge, skills and } \\
\text { perspectives about conceptual teaching methods, was } \\
\text { developed, implemented and researched its impact. }\end{array}$ & $\begin{array}{l}40 \text { hours } \\
10 \text { days }\end{array}$ & $\begin{array}{l}\text { Karadeniz } \\
\text { Tech. Uni. } \\
\text { Ph.D. } \\
\text { Trabzon }\end{array}$ & $\begin{array}{l}\text { Workshop } \\
25 \text { teachers }\end{array}$ \\
\hline $\begin{array}{l}\text { Şenel, } \\
2008\end{array}$ & $\begin{array}{l}\text { The researcher developed an IST course program with the } \\
\text { aim of supporting teachers' professional development on } \\
\text { student portfolio file, performance evaluation, constructive } \\
\text { grid and diagnostic tree that are among alternative } \\
\text { measurement and assessment techniques and investigated } \\
\text { its impact. }\end{array}$ & $\begin{array}{l}30 \text { hours } \\
5 \text { weeks }\end{array}$ & $\begin{array}{l}\text { Karadeniz } \\
\text { Tech. Uni. } \\
\text { Masters } \\
\text { Trabzon }\end{array}$ & $\begin{array}{l}\text { Workshop } \\
6 \text { teachers }\end{array}$ \\
\hline $\begin{array}{l}\text { Balta, } \\
2014\end{array}$ & $\begin{array}{l}\text { It offered an IST course model in which teachers of } \\
\text { adjacent schools meet once a week, explain the topic that } \\
\text { they will present to their students in the next week to one } \\
\text { another, discuss it and shared their experiences for their } \\
\text { professional development, organized the course and } \\
\text { investigated its impact. }\end{array}$ & $\begin{array}{l}21 \text { hours } \\
7 \text { weeks }\end{array}$ & $\begin{array}{l}\text { METU } \\
\text { Ph.D. Ankara }\end{array}$ & $\begin{array}{l}\text { Workshop } \\
6 \text { teachers }\end{array}$ \\
\hline $\begin{array}{l}\text { Yadigaroğlu, } \\
2014\end{array}$ & $\begin{array}{l}\text { It developed, applied and searched the effectiveness of an } \\
\text { in-service training course for chemistry teachers which } \\
\text { aimed to increase their technological pedagogical content } \\
\text { knowledge. }\end{array}$ & $\begin{array}{l}40 \text { hours } \\
10 \text { days }\end{array}$ & $\begin{array}{l}\text { Karadeniz } \\
\text { Tech. Uni. } \\
\text { Ph.D. } \\
\text { Trabzon }\end{array}$ & $\begin{array}{l}\text { Workshop } \\
15 \text { teachers }\end{array}$ \\
\hline
\end{tabular}

\subsection{Statistical Analysis}

The homogeneous distribution values, average effect sizes and confidence intervals of the studies included in meta-analysis according to fixed effect and random effect models were given in Table 4. The average effect size values for the effect of the organized IST courses on teachers in fixed effects model and random effects models are 3.526 and 3.819 respectively. For the five degrees of freedom and $95 \%$ significance level the critical value is given approximately as 11.07 in Chi-square table. It can be stated that the distribution of effect sizes have heterogeneous structure since Q statistical value 38.196 , calculated in this research, is greater than the critical value, which is 11.07 . Moreover, the $\mathrm{I}^{2}$ index indicates the percentage of the total variability in the effect sizes due to true heterogeneity, that is, to between-studies variability. Percentages of around 25\%, 50\%, and $75 \%$ would mean low, medium, and high heterogeneity, respectively (Higgins \& Thompson, 2002). So, the $\mathrm{I}^{2}$ value, 86.910, calculated in this meta-analysis indicates a high heterogeneity. Since the distribution in effect sizes has a heterogeneous structure, analysis, suitable for random effects model, were conducted in order to reveal the effectiveness of IST courses.

Table 4. Table for Heterogeneity, Effect Sizes, Confidence Intervals and Test of null Hypothesis According to Statistical Models

\begin{tabular}{|c|c|c|c|c|c|c|c|c|c|c|c|}
\hline Model & \multicolumn{6}{|c|}{ Effect Size and $\% 95$ Confidence Interval } & \multicolumn{2}{|c|}{$\begin{array}{c}\text { Test of null } \\
\text { (2-Tail) }\end{array}$} & \multicolumn{3}{|c|}{ Heterogeneity } \\
\hline Model & $\mathrm{N}$ & ES $(g)$ & $\begin{array}{l}\text { S. } \\
\text { error }\end{array}$ & Variance & $\begin{array}{c}\text { Lower } \\
\text { limit }\end{array}$ & $\begin{array}{l}\text { Upper } \\
\text { limit }\end{array}$ & $\begin{array}{c}\text { Z-valu } \\
\text { e }\end{array}$ & $\begin{array}{c}\text { P-valu } \\
\text { e }\end{array}$ & $Q(d f)$ & $\begin{array}{c}\text { P-valu } \\
\text { e }\end{array}$ & $\mathrm{I}^{2}$ \\
\hline Fixed & 6 & 3.526 & 0.246 & 0.06 & 3.044 & 4.008 & 14.349 & 0.000 & 38.196 & & \\
\hline Random & 6 & 3.819 & 0.710 & 0.504 & 2.428 & 5.210 & 5.381 & 0.000 & $(5)$ & 0.000 & 86.910 \\
\hline
\end{tabular}

Table 4 shows that the effect size value to be 3.819 and the upper and lower bounds of $95 \%$ confidence interval to be 2.428 and 5.210 according to random effects model provided in five studies that were included in meta-analysis as a result of eliminations. The effect size value appears in the large interval according to Cohen's (1998) classification. Accordingly, the organized IST courses can be said to be quite effective. Since only five studies (six effect sizes) were found for this meta-analysis, sub-group analysis were not conducted.

IST course, organized by the researchers, were also analyzed in terms of the features of effective professional development programs. The programs, in which participants are from a province, from a school or teachers of a certain subject, were considered "collective participation" while filling Table 5. Courses, which involve 3 hour or more activities per week, were accepted as "intensive" (Balta, 2014). Courses, designed according to the needs of teachers or institutions, were considered "coherence." Course, spread for the period longer than 6 months, were accepted as 
"long-term." Since "sustained" and "job embedded" features were not found at any course, they were not added to the table.

Table 5. Effective IST Course Characteristics of the Studies

\begin{tabular}{|c|c|c|c|c|c|c|c|c|}
\hline Study & $\begin{array}{l}\text { Needs } \\
\text { Analysis } \\
\text { Conducted }\end{array}$ & $\begin{array}{l}\text { Collective } \\
\text { Participation }\end{array}$ & $\begin{array}{l}\text { Active } \\
\text { Participation }\end{array}$ & $\begin{array}{l}\text { Focus on } \\
\text { Content } \\
\text { Knowledge }\end{array}$ & Intensive & Long-term & $\begin{array}{l}\text { Expert } \\
\text { Opinion } \\
\text { Taken } \\
\end{array}$ & $\begin{array}{l}\text { Pilot } \\
\text { Study }\end{array}$ \\
\hline Metin, 2010 & $\sqrt{ }$ & $\sqrt{ }$ & $\sqrt{ }$ & .. & $\sqrt{ }$ & .. & $\sqrt{ }$ & $\sqrt{ }$ \\
\hline Tekin, 2004 & $\sqrt{ }$ & $\sqrt{ }$ & $\sqrt{ }$ & .. & $\sqrt{ }$ & .. & $\sqrt{ }$ & $\sqrt{ }$ \\
\hline Şenel, 2008 & $\sqrt{ }$ & $\sqrt{ }$ & .. & .. & $\sqrt{ }$ & .. & $\sqrt{ }$ & .. \\
\hline Balta, 2014 & $\sqrt{ }$ & $\sqrt{ }$ & $\sqrt{ }$ & $\sqrt{ }$ & $\sqrt{ }$ & .. & $\sqrt{ }$ & $\sqrt{ }$ \\
\hline $\begin{array}{l}\text { Yadigaroğlu, } \\
2014\end{array}$ & $\sqrt{ }$ & $\sqrt{ }$ & $\sqrt{ }$ & .. & $\sqrt{ }$ & .. & $\sqrt{ }$ & $\sqrt{ }$ \\
\hline
\end{tabular}

As seen in Table 5, studies contain the characteristics of effective IST course at high levels. In this meta-analysis, courses, which accommodate 6 and more characteristics, are accepted as high quality. Nevertheless none of the five theses comprises the feature "long term".

Forest plot is one of the key elements which enables the visual representation of results of meta-analysis (Borenstein, 2005). The forest plot obtained from Comprehensive Meta-Analysis Software for this study is depicted in Figure 2. It represents the effect sizes of five studies synthesized to reveal the effect of IST courses on teacher achievement. The individual squares represent the effect size estimates of each study and the lines extending across squares indicate the limits of the $95 \%$ confidence interval. The size of each square corresponds to the weight (also proportional to sample size) of the individual studies in the meta-analyzes. The overall effect size estimate from the meta-analysis in random effect model and its confidence interval is represented by a diamond located at the bottom of the plot.

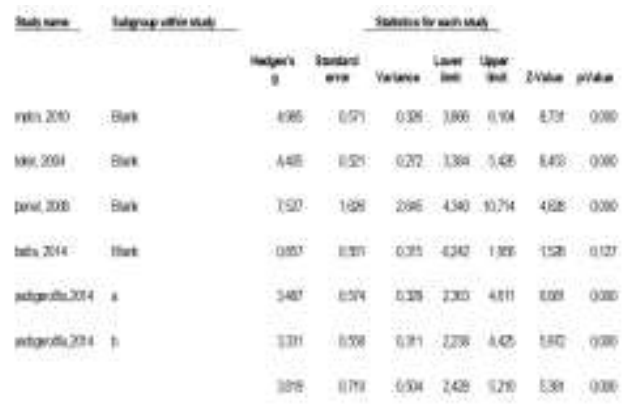

Figure 2. Forest plot interienas o

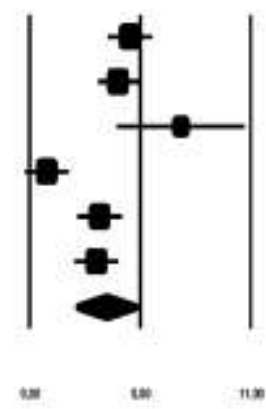

After following steps of a comprehensive meta-analysis in this study, a total of five thesis works, which study the effectiveness of IST courses, were identified. Articles that measure the effectiveness of IST courses were not included in this meta-analysis. The main reason for this is that no research that quantitatively search the effectiveness of IST course was found neither in SSCI journals published in Turkey on education (except Tekin's article version of thesis work in 2004) nor educational journals of the universities after unsystematic review of the literature. The failure to encounter articles in this area may be due to (a) conducting needs analysis, (b) organizing IST courses, and (c) the execution of the course being a troublesome process.

All of the studies evaluated in this meta-analysis provided the current researchers the data that they can use to calculate the effect sizes and carry out re-analysis. The positive effects of IST courses on the participants have been found in all of these studies conducted by scientific research methods. All studies in this meta-analysis preferred the single group pre-test and post-test design. The difficulty of forming two equal groups in terms of participants being teachers and prior knowledge, generally directs researchers to studies that have single group pre-test and post-test design. In the literature, researches, which study the effect of the course on student achievement, are only considered to be experimental studies. In this respect, the researchers in Turkey should go beyond the effect of IST courses on teachers' achievement and conduct experimental studies, that is, the studies on the effect of IST courses on student achievement.

In terms of duration, all studies was completed more than the critical 14 hours (Yoon, 2007) which was set for effective professional development programs. Courses were organized with the duration of lowest 21 hours (Balta, 2014) and the highest 60 hours (Metin, 2010). It is an expected result for these courses to produce mostly high effect sizes since both average activity duration (38,2 hours) and average course durations (23,2 days) were adequate. In addition, all of the studies included in meta-analysis of being thesis works and teachers' active participation in IST programs prepared within these thesis works caused the effectiveness of IST courses to be higher. 
On the other hand, the obtained high effect sizes in all of these studies may arise from the fact that all of these IST courses were organized in the form of workshops. If teachers took an active role in the organized IST courses, then this organized course was evaluated as workshop. In this respect, IST courses, in all of the studies included in meta-analysis, were organized in the form of workshops. Only what kind of role teachers took was not mentioned in IST course done in Şenel's (2008) study. But the IST course, conducted in that study, was accepted as workshop when looking at the content of IST course program and considering the similar features of the studies conducted at the same university. Since no studies, related to IST courses, organized in the form of seminars were identified in this meta-analysis research, there is no possibility to make any comparisons between workshops and seminars.

No relationship was also found between the contact hours of IST courses, course duration and effect size. The insignificant correlations -0.226 and 0.281 between duration and effect size, and between contact hours and effect size were found respectively.

The contents of the IST courses that were organized by the selected five studies were also analyzed in this meta-analysis. A few common characteristics were identified in the courses with higher effect sizes. These courses are the courses in which needs analysis were conducted before the implementation, expert opinions were taken, pilot study was conducted, experienced educators took part and intensive training (contact hours /duration more than 3 hours/week) was provided.

\section{Conclusions, Suggestions and Limitations}

\subsection{Conclusions}

The following conclusions can be made based on the findings of this meta-analysis;

(a) No enough theses works that research the effectiveness of IST were conducted,

(b) IST courses, organized within the theses works conducted in this area, have been very effective,

(c) The effect sizes, displaying the effectiveness of IST courses, are distributed in a wide range between 0.86 and 7.53 according to Cohen's $d$. This distribution indicates that the effectiveness of IST courses may be quite different,

(d) High effect sizes (ES=3.819 on average) of the five studies in accordance with random effects model showed at the end of the meta-analysis that the effects of IST courses are relatively high on teachers' achievement,

(e) The first thesis work, searching the effect of IST course quantitatively, was conducted in 2004 and five such theses works were conducted in the period of ten years. According to this, searching the effectiveness of IST has emerged to be an area that was studied very little by the researchers.

\subsection{Suggestions}

The results obtained will be enough to provide suggestions for the future studies as well as for educators.

- The most important indicator for the success of an organized IST course is the positive changes in students' achievement. Therefore, there is a need for experimental studies that examine the relationship between IST course and student success.

-There is a need for studies harboring "sustained" and "job embedded" features that are characteristics of effective IST courses.

-Since IST courses, organized for thesis at universities, have higher effect sizes, similar courses can be organized by the General Directorate of Teacher Training and Development throughout Turkey.

-Various constructs, such as teachers' and students' achievements and attitudes, can be measured before and after the courses in order to determine the effectiveness of IST courses organized each year across the country by General Directorate of Teacher Training and Development.

-Studies, which compare the effectiveness of IST courses organized in the framework of theses works and organized by the General Directorate of Teacher Training and Development, can be conducted.

-The organization and implementation of standard-based IST courses can be realized through the partnership of universities.

-Standard-based and automated IST system should be created in order to increase IST courses organized annually by the Ministry of Education and to render them comprehensive.

- The characteristics of an effective IST course, identified by the literature such as executed easily, enabling collective participation, making active learning possible, increasing content knowledge, coherence, intensive, sustained, long-term and job embedded, can be integrated into the courses organized in Turkey.

-During the literature search, various constructs, such as attitude, achievement, skill, self-efficacy, self-report and belief, 
of the participants (teachers, students and parents) in the organized IST courses were found. Other meta-analysis studies can be conducted to synthesize the results of the theses for each of these constructs.

\subsection{Limitations}

This meta-analysis was restricted in several ways. First, a small number of studies were identified and included in the meta-analysis. This relatively small number of studies have reduced the reliability of generalizing the results. Second, the criterion "studies carried out in Turkey" led to small number of studies in the area of IST. This criterion can be removed and the international perspective can be adopted in future meta-analysis on the effect of IST courses on teachers' achievement.

\section{References}

Aktüel, E. (2014). Öğretmen saylsı ne kadar? (2013-2014). http://www.aktuelegitim.com/ogretmen-sayisi-ne-kadar-2013-2014.html.

Balta, N. (2014). The effect of a professional development program on physics teachers' knowledge and their students' achievement in modern physics unit. Unpublished Doctoral dissertation, Middle East Technical University, Ankara.

Birman, B. F., Desimone, L., Porter, A. C., \& Garet, M. S. (2000). Designing professional development that works. Educational Leadership, 57(8), 28-33.

Blank, R. K., \& Alas, N. L. (2010). Effects of Teacher Professional Development on Gains in Student Achievement: How Meta-Analysis Provides Scientific Evidence Useful to Education Leaders. 2010 SREE Conference Abstract Template.

Borenstein, M. (2005). Software for Publication Bias. In H. R. Rothstein, A. J. Sutton \& M. Borenstein (Eds.), Publication Bias for Meta-Analysis: Prevention, Assessment and Adjustments. West Sussex, England: John Wiley \& Sons Ltd. http://dx.doi.org/10.1002/0470870168.ch11

Borko, H. (2004). Professional Development and teacher learning: Mapping the terrain. Educational Researcher, 33(8), 3-15. http://dx.doi.org/10.3102/0013189X033008003

Castillo, R., Fernández-Berrocal, P., \& Brackett, M. A. (2013). Enhancing teacher effectiveness in Spain: A pilot study of the RULER approach to social and emotional learning. Journal of Education and Training Studies, 1(2), 263-272. http://dx.doi.org/10.11114/jets.v1i2.203

Cohen, J. (1988). Statistical power analysis for the behavioral sciences. Hillsdale, NJ: Lawrance Erlbaum Associates, Inc.

Corcoran, T. B. (2007). Teaching matters: How state and local policymakers can improve the quality of teachers and teaching. Consortium for Policy Research in Education, RB 48.

Damar, M. (1996). İlkokuma Yazma Öğretiminde Karşılaşılan Güçlüklerle Öğretmen Nitelikleri Arasındaki İlişki. Unpublished master thesis, Hacettepe University, Ankara.

Darling-Hammond, L., \& McLaughlin, M. W. (1996). Policies that support professional development in an era of reform. Phi Delta Kappan, 76(8), 597-604.

Demirtaş, Z. (2010). As a tool for traning teacher in service, supervision. Electronic Journal of Social Sciences, 9(31), 41-52.

Desimone, L. M. (2009). Improving Impact Studies of Teachers' Professional Development: Toward Better Conceptualizations and Measures. Educational Researcher, 38(3), 181-199. http://dx.doi.org/10.3102/0013189X08331140

Dori, Y. J., \& Herscovitz, O. (2005). Case-based Long-term Professional Development of Science Teachers. International Journal of Science Education, 27(12), 1413-1446. http://dx.doi.org/10.1080/09500690500102946

Fendler, L. (2003). Teacher reflection in a hall of mirrors: historical influences and political reverberations. Educational Researcher, 32(3), 16-25. http://dx.doi.org/10.3102/0013189X032003016

Garet, M. S., Porter, A. C., Desimone, L. M., Birman, B. F., \& Yoon, K. S. (2001). What makes professional development effective? Results from a national sample of teachers. American Educational Research Journal, 38(4), 915-945. http://dx.doi.org/10.3102/00028312038004915

Glass, G. V. (1976). Primary, secondary, and meta-analysis of research. Educational Researcher, 5(10), 3-8. http://dx.doi.org/10.3102/0013189X005010003

Gönen, S. \& Kocakaya, S. (2006). An evaluation of high school physics teachers' opinions about inservice-education. 
Pamukkale University Journal of Education, 19(19), 37-44.

Günbayi, İ. \& Taşdöğen, B. (2012). Compulsory school teachers' views on in-service education programs: a case study, Journal of the human and social science researches, 1(3), 113-114.

Guskey, T. R. (2003). Characteristics of effective professional development: A synthesis of list. ERIC Document Reproduction Service Number ED 478380.

Hawley, W. D., \& Valli, L. (1998). The essentials of effective professional development: A new consensus. In L. S. Darling Hammond \& G. Sykes (Eds.), The heart of the matter: Teaching as a learning profession (pp. 86-124). San Francisco: Jossey-Bass.

Hewson, P. W. (2007) Teacher Professional development in science. Handbook of research on science education. Lawrence Erlbaum Associates Publis. Matwah, New Jersay.

Higgins, J. P. T., \& Thompson, S. G. (2002). Quantifying heterogeneity in a metaanalysis. Statistics in Medicine, 21, 1539-1558. http://dx.doi.org/10.1002/sim.1186

Hizmet içi eğitim planı (2014). 2012 yılı Hizmetiçi Eğitim Planı. http://personel.meb.gov.tr/www/ icerik_goruntule.php?KNO=108

Joyce, B., \& Showers, B. (2002). Student achievement through staff development (3rd ed.). Alexandria, VA: Association for Supervision and Curriculum Development.

Loucks-Horsley, S. (1995). Professional development and the learner-centered school. Theory into Practice, 34, 265-271. http://dx.doi.org/10.1080/00405849509543690

MEB, (2008). Sınıf öğretmenlerinin hizmet içi ĕgitim ihtiyacının belirlenmesi, Ankara: MEB EARGED

Meta-Analysis, Education and Science, 39(174), 1-32. http://dx.doi.org/10.15390/EB.2014.3379

Metin, M. (2010). Effectiveness of Preparing In Service Training Programs for Science and

Office for Official Publications of the European Union. (2010). An analysis of teachers' professional development based on the OECD's Teaching and Learning International Survey (TALIS). http://ec.europa.eu/education/school-ducation/doc/talis/report_en.pdf

Öğretmen yetiştirme ve geliştirme genel müdürlüğü. (2012). 2012 Hizmetiçi Eğitim Planı. http://hedb.meb.gov.tr/

Önen, F., Mertoğlu, H., Saka, M., \& Gürdal, A. (2009). The Effects of In-Service Training on Teachers' Knowledge about Teaching Methods and Techniques: Öpyep Case. Journal of Kirşehir Education Faculty, 10(3), 9-23.

Şenel, T. (2008). Investigating the Effectiveness of In-Service Course Programme for Science and Technology Teachers About Alternative Measurement and Assessment Technics. Unpublished master dissertation, Karadeniz Technical University, Trabzon.

Tanrıverdi, K., \& Günel, M. (2012). Öğretmen Pedagojisinde Kritik Sorun: Değişime Karşı Direnç. X. National Science and Mathematics Education Congress (UFBMEK), Niğde, Turkey.

Teachers' Knowledge and Skills about Technological Pedagogical Content Knowledge Model and Investigating its Effectiveness, Unpublished Doctoral dissertation, Karadeniz Technical University, Trabzon.

Technology Teachers on Performance Assessment, Unpublished Doctoral dissertation, Karadeniz Technical University, Trabzon.

Tekin, S. (2004). Development of an in-service programme concerning conceptual understanding and concept teaching for chemistry teachers and investigation of its influence in practice. Unpublished Doctoral dissertation, Karadeniz Technical University, Trabzon.

Üstün, U., \& Eryılmaz, A. (2014). A Research Methodology to Conduct Effective Research Syntheses:

Yadigaroğlu, M. (2014). Developing an In-Service Training Programme for Improving Chemistry

Yoon, K. S., Duncan, T., Lee, S. W.-Y., Scarloss, B., \& Shapley, K. (2007). Reviewing the evidence on how teacher professional development affects student achievement (Issues \& Answers Report, REL 2007-No. 033). http://ies.ed.gov/ncee/edlabs/regions/southwest/pdf/REL_2007033.pdf

\section{(cc) BY}

This work is licensed under a Creative Commons Attribution 3.0 License. 